\title{
Accounting Students' Academic Performance by Their Background Information
}

\author{
Siti Antika Sari ${ }^{1}$, Ani Wilujeng Suryani ${ }^{2, *}$ \\ Universitas Negeri Malang Jl. Semarang No.5, Sumbersari, Kec. Lowokwaru, Kota Malang, 65145 Indonesia \\ Itikasari886@gmail.com, ${ }^{2}$ ani.suryani@um.ac.id \\ * corresponding author
}

\begin{abstract}
\begin{tabular}{l|l} 
ARTICLE INFO ABSTRACT
\end{tabular}
Article history

Received June 25, 2020

Revised Dec 16, 2020

Accepted Dec, 19, 2020

Keywords

Academic performance gender

Living environment

Educational funding

Scholarship

This study aims to determine differences in academic performance of accounting students by their background information. This study involved secondary data from 810 accounting students, analyzed by using Kruskal Wallis test to investigate differences on gender, living environment and funding source. The results show that the academic performance of female students who live at home and obtain scholarship are better than other groups. However, males who live at home and obtain scholarship have indifferent academic performance from other male groups. These findings indicate that gender, living environment and type of educational funding can be taken into consideration to differentiate students' aca-demic performance. The results of this study can be used by universities to make decisions in determining acceptance criteria, to identify potential students to increase academic performance, and to resolve problems of underperformed students. This research provides an evidence that females and males have different academic performance. Moreover, we found that females who obtained scholarship maintain their high performance, while males are indifferent in their academic performance irrespective of their source of funding.

Penelitian ini bertujuan untuk mengetahui perbedaan kinerja akademik mahasiswa akuntansi berdasarkan background information mereka. Penelitian ini menggunakan data akademik dari 810 mahasiswa akuntansi Universitas Negeri Malang, dianalisis dengan menggunakan uji Kruskal Wallis. Hasil penelitian menunjukkan bahwa kinerja akademik mahasiswa perempuan yang tinggal di rumah dan mendapatkan Bidikmisi lebih baik daripada kelompok mahasiswa lainnya. Namun, kinerja akademik mahasiswa laki-laki yang tinggal di rumah dan mendapatkan Bidikmisi tidak lebih baik dari kelompok mahasiswa laki-laki lainnya. Hasil temuan ini menunjukkan bahwa gender, lingkungan tempat tinggal, dan jenis bantuan pendidikan dapat digunakan untuk membedakan kinerja akademik mahasiswa. Hasil penelitian ini dapat digunakan oleh perguruan tinggi untuk membuat keputusan dalam menentukan kriteria yang diterima, mengidentifikasi mahasiswa yang memiliki kinerja akademik yang baik, dan mengatasi masalah kinerja akademik mahasiswa yang kurang maksimal.
\end{abstract}

This is an open access article under the $\mathrm{CC}-\mathrm{BY}$ license.

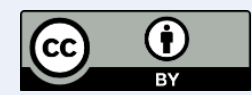

\section{Introduction}

Academic performance is the achievement of a goal or work output for a learning that has been done by students optimally (Mandias, 2015). Academic performance is an important aspect that must be achieved by each student because it reflects students' ability during university study. Measurement of the success rate of academic performance requires the existence of clear indicators. The main indicator that shows success academic performance achieved by students in higher education levels is the Grade Point Average (GPA) (K. A. Alanzi, 2018; Mortenson, 2005; Pascarella \& Terenzini, 1991). GPA is the re- sult of studies that have been taken by students from all courses in a semester (Rofi'uddin, 2015). Through this GPA, the attainment of students' academic performance is visible (Kurniawan et al., 2016).

Recently, globalization and the development of the business resulted in the development of various professions and occupations. The ac-counting profession is one, among other professions, that experiences rapid development. Knowledge of accountants helps meet the needs of financial users and provides non-financial in-formation, so that it shares added values and supports careers of the surrounded community (Klibi \& Oussii, 2013; Wirianata, 2017). For 
accountants' position in the workplace, the GPA is needed and is one of the initial assessments to measure level of understanding of the theory and application during lectures (Okezone, 2018). In addition, many companies offer job application selections based on students' performance such as in the form of GPA (Nilawati \& Bimo, 2010). The Ministry of Education (MoE), Republic of Indonesia, have issued a decree number 232/U/2000 concerning Guidelines for Compilation Higher Education Curriculum and Student Learning Outcomes Assessment in article 14 , mentioning that the educational program graduation requirements determined on the fulfillment of the required number of SKS and minimum GPA. Given the importance of academic performance as indicated by the GPA. It is necessary for university stakeholders to help enhance students' academic performance.

One of the plausible endeavors to improve students' academic performances is through analyzing the academic performance from their background information. By so doing, universities are expected to determine the curriculum, student acceptance criteria, and the understanding of students' potentials (Koh \& Koh, 1999).

Among the many background information's researchers generally examine, gender, living environment, and types of educational funding are worthinvestigating (K. A. Alanzi, 2018; Bartik \& Lachowska, 2014; Buba \& Umar, 2015; Cutrona et al., 1994; Du, 2011; Elias, 2005; Fallan \& Opstad, 2014; Fogarty \& Goldwater, 2010; B. Hasanah, 2014; Lawrence et al., 2006; Li, 2012; M. AlAwadhi \& Alhashel, 2020; Sarwar, 2012; Smith, 2004; Sucahyo \& Muhammad, 2014; M. Syah, 2014; P. Utomo, 2011; Wall et al., 1999; D. Waskito \& Azizah, 2013). Previous research shows different results, informing students' academic performance (Byrne \& Flood, 2003, 2005, 2008; Duff*, 2004; Garkaz et al., 2011; Gracia \& Jenkins, 2003; Newman-Ford et al., 2009). Meanwhile, other studies measured differences in students' academic performance employing one variable. Therefore, to expand empirical findings of students' academic performance research in higher education contexts, the present study employs and combines three variables, namely gender (male and female), living environment (live at home and live at boarding house) and type of educational funding (Bidikmisi and non Bidikmisi) to find differences in academic performance.

In terms of education, female students are considered to have well-ordered personality in learning and motivation for strong learning (Smith, 2004). On the other hand, male students do not rule out the possibility of having potential similar academics. It is due to the demands of obligations in the future (Paver \& Gammie, 2005). Female and male students are engaged in learning due to environmental factors such as home environment that forms students to study more diligently (Cutrona et al., 1994; Du, 2011; M. Al-Awadhi \& Alhashel, 2020). Another factor is the type educational funding sources they earned, namely Bidikmisi or independent funding. Environmental conditions and funding sources have been predicted to motivate them to perform better if compared to that of other groups of students (Sucahyo \& Muhammad, 2014; D. Waskito \& Azizah, 2013). Hence, in this study, a hypothesis is proposed:

H1: Academic performance of female students who live at home and obtain Bidikmisi scholarship are better than the other female student groups based on living environment and type of educational funding.

$\mathrm{H} 2$ : Academic performance of male students who live at home and obtain Bidikmisi scholarship are better than the other male student groups based on living environment and type of educational funding.

Several previous studies have informed that female students have better academic performance than that of male students (K. A. Alanzi, 2018; Buba \& Umar, 2015; Elias, 2005; Fallan \& Opstad, 2014; Fogarty \& Goldwater, 2010; Lawrence et al., 2006; M. Al-Awadhi \& Alhashel, 2020; Sarwar, 2012; Smith, 2004). It is because female students are better in terms of accuracy and equality in thinking (Krutetskii, 1976). Thus, such a character is needed to achieve performance good academic.

Academic performance of female students is also influenced by environment. One of which is the home environment (Purwanto, 2019), such as motivation and direct role of parents who very helpful in the learning process of a student, so they are more encouraged to improve their academic performance (B. Hasanah, 2014).

The existence of educational funding has also an impact on academic performance, in-clouding Bidikmisi scholarship. Female students who have been given more educational funding are motivated to deliver better academic performance (Sucahyo \& Muhammad, 2014; D. Waskito \& Azizah, 2013). The demand from education aid providers is also encouraging for Bidikmisi students to produce better academic performance compared to other students especially male students (Bartik \& Lachowska, 2014; Sucahyo \& Muhammad, 2014; D. Waskito \& Azizah, 2013). Hence, we argue that H3: Academic performance of female students who live at home and obtain Bidikmisi scholarship are better than the other student groups based on living environment and type of educational funding. 
This study aims to determine differences in academic performance of accounting students by their background information. Since previous studies only employed one variable, the present study uses three variables, namely gender (male and female), living environment (live at home and live at boarding house) and type of educational funding (Bidikmisi and non Bidikmisi) to find the difference in academic performance.

\section{Method}

This research employed a comparative quantitative design to data gathering. The secondary academic data from Department of Accounting, Universitas Negeri Malang, were collected. This research re- cruited the active students majoring in Accounting class of 2015 to 2018 on the grounds that the number of undergraduate accounting students fluctuated from 2015 to 2018, making it intrigue to be a sample. The presentation of this sample is shown in Table 1. Table 2 shows the variables and indicators used in this research.

Table 1. Characteristics of Research Samples by Force

\begin{tabular}{cc}
\hline Force & Number of Students \\
\hline 2015 & 203 \\
2016 & 233 \\
2017 & 183 \\
2018 & $\underline{191}$ \\
Total & 810 \\
\hline
\end{tabular}

Table 2. Research Variables

\begin{tabular}{|c|c|c|c|}
\hline Variables & Symbo & Indicators & References \\
\hline Gender & $\mathrm{X} 1$ & $\begin{array}{c}\text { Male } \\
\text { Female }\end{array}$ & $\begin{array}{l}\text { (K. a Alanzi, 2018; Trianasari Angkawijaya \& Sugiarti, } \\
\text { 2014) }\end{array}$ \\
\hline Living environment & $\mathrm{X} 2$ & $\begin{array}{l}\text { Live at home } \\
\text { Live at boarding house }\end{array}$ & (Ford et al., 2009; Hasanah, 2014; Syah, 2014) \\
\hline $\begin{array}{l}\text { Type of educational } \\
\text { funding }\end{array}$ & $\mathrm{X} 3$ & $\begin{array}{l}\text { Bidikmisi } \\
\text { Non bidikmisi }\end{array}$ & (Pramudi Utomo, 2011; Danang Waskito \& Azizah, 2013) \\
\hline Academic performance & Y & $\begin{array}{l}\text { Grade Point Average } \\
\text { (GPA) }\end{array}$ & $\begin{array}{l}\text { (K. a Alanzi, 2018; Trianasari Angkawijaya \& Sugiarti, } \\
\text { 2014) }\end{array}$ \\
\hline
\end{tabular}

In this analysis, prior to testing the hypothesis, it is necessary to have the classic assumption test in the form of a normality test. This research has fulfilled classic assumption test requirements to obtain good analysis results, namely: the academic performance variable has the value of $\mathrm{z}$ skewness and $\mathrm{z}$ kurtosis no between -3 and +3 , so the data are not normally distributed. Therefore, the hypothesis testing used a non-parametric test. Nonparametric test was used to test differences between groups of students in terms of gender, living environment, and type of educational funding, and the analysis employed the Kruskal Wallis test (Leech et al., 2005).
Results of Kruskal Wallis test that indicate a difference was followed by a post hoc test, namely the Mann Whitney test. the purpose of post hoc test was to find out whether there was inter-groups significant difference. If the Kruskal Wallis test results did not show difference, then there was no need to conduct a post hoc test.

\section{Results and Discussion}

Table 3 shows the results of descriptive statistics on academic performance accounting students based on background information.

Table 3. Descriptive Statistics

\begin{tabular}{lccccc}
\hline & N & Minimum & Maximum & Mean & Std. Deviation \\
\hline Ml, home, Bm & 7 & 3.24 & 3.60 & 3.45 & 0.13 \\
Ml, home, non Bm & 59 & 2.44 & 3.78 & 3.37 & 0.28 \\
Ml, boarding h, Bm & 27 & 2.69 & 3.84 & 3.44 & 0.31 \\
Ml, boarding h, non Bm & 128 & 1.26 & 3.85 & 3.33 & 0.37 \\
Fm, home, Bm & 32 & 2.98 & 3.86 & 3.57 & 0.19 \\
Fm, home, non Bm & 114 & 0.69 & 3.93 & 3.47 & 0.35 \\
Fm, boarding h, Bm & 87 & 2.93 & 3.90 & 3.51 & 0.23 \\
Fm, boarding h, non Bm & 356 & 0.35 & 4.00 & 3.42 & 0.31 \\
\hline
\end{tabular}

Table 3 shows that overall female students have mean values, indicating that they were better than male students. The students who live at home also show a higher mean than that of students who live at boarding houses and obtain the Bidikmisi scholarship. These influence their academic performance. This finding shows that students who live at home and obtain Bidikmisi scholarship have better aca- 
demic performance. Table 4 shows the results of a Kruskal Wallis test between academic performance students based on background information of female students.

Table 4. Kruskal Wallis Test of Academic Performance based on Background Information (Female Students Group)

\begin{tabular}{|c|c|c|c|c|c|c|}
\hline \multirow[t]{3}{*}{ Gender } & \multirow[t]{3}{*}{ Living Environment } & \multicolumn{4}{|c|}{ Type of Educational Funding } & \multirow[t]{3}{*}{ p-value } \\
\hline & & \multicolumn{2}{|c|}{ Bidikmisi } & \multicolumn{2}{|c|}{ Non Bidikmisi } & \\
\hline & & $N$ & Mean Rank & $N$ & Mean Rank & \\
\hline \multirow[t]{2}{*}{ Female } & Live at home & 32 & $368 . .09$ & 114 & $313 . .09$ & $0 . .00$ \\
\hline & Live at boarding house & 87 & 330.41 & 356 & 273.79 & \\
\hline
\end{tabular}

Table 4 portrays the results of the Kruskal Wallis test of female student and informs that the p-value < 0.05 is obtained (H01 rejected), which means that the academic performance of female students who live at home and obtain Bidikmisi scholarship are better than the other female students based on living environment and type of educational funding. Female students who live at home and obtain Bidikmisi scholarship significantly have a higher average rank (368.09) than the other female students.

Table 5 shows the results of a Kruskal Wallis test of students' academic performance based on background information, namely gender, living environment and type of educational funding of male students.

Table 5. Kruskal Wallis Test of Academic Performance based on Background Information (Male Students Group)

\begin{tabular}{ccccccc}
\hline Gender & Living Environment & \multicolumn{3}{c}{ Type of Educational Funding } & \multirow{2}{*}{ p-value } \\
\cline { 3 - 6 } & & \multicolumn{2}{c}{ Bidikmisi } & Non Bidikmisi & \\
& & $\boldsymbol{N}$ & Mean Rank & $\boldsymbol{N}$ & Mean Rank & \\
\hline \multirow{2}{*}{ Male } & Live at home & 7 & 125.43 & 59 & 110.84 & 0.43 \\
& Live at boarding house & 27 & 127.69 & 128 & 106.77 & \\
\hline
\end{tabular}

Table 5 shows the results of the Kruskal Wallis test of the male students and informs the p-value > 0.05 (H02 accepted) which means the male students' academic performance who live at home and obtain Bidikmisi scholarship are indifferent from other male students based on living environment and type of educational funding.
Table 6 shows the results of a Kruskal Wallis test of students' academic performance based on background information, namely gender, living environment and type of educational funding of all students group.

Table 6. Kruskal Wallis Test of Academic Performance based on Background Information (All Group)

\begin{tabular}{ccccccc}
\hline \multirow{2}{*}{ Gender } & Living Environment & \multicolumn{3}{c}{ Type of Educational Funding } & \multirow{2}{*}{ p-value } \\
\cline { 3 - 6 } & & \multicolumn{3}{c}{ Bidikmisi } & Non Bidikmisi & \\
& & Mean Rank & N & Mean Rank & \\
\hline \multirow{2}{*}{ Male } & Live at home & 7 & 385.29 & 59 & 348.03 & 0.00 \\
& Live at boarding house & 27 & 417.15 & 128 & 334.57 & \\
Female & Live at home & 32 & 526.09 & 114 & 452.08 & \\
& Live at boarding house & 87 & 452.08 & 356 & 397.52 & \\
\hline
\end{tabular}

Based on table 6 the results of the Kruskal Wallis test show that the value p-value $<0.05$ (H03 rejected), which means the academic performance of female students who live at home and obtain Bidikmisi scholarship are better than the other student groups based on living environment and type of educational funding. Female student who lives at home and obtained Bidikmisi scholarship are significantly average ranked higher (526.09) than the other student groups. Based on the results of the Kruskal Wallis test above it is known that $\mathrm{H} 01$ and $\mathrm{H} 03$ shows a difference, so that further testing is needed (post hoc test) with Mann Whitney. Meanwhile, for H02 it is not necessarily post-toc test because it shows there is no difference. Test result this can be seen in Table 7 .

The results of the post hoc test analysis with Mann Whitney above show that the p-value varies, there are differences in academic performance which is not significant between the groups of females who live at home and non Bidikmisi, female who live in boarding houses and Bidikmisi, male who live at home and Bidikmisi and male who live at boarding houses and Bidikmisi on all groups of females (pvalue $>0.05$ ). The analysis also shows different results were in the group of females who live in boarding house and non Bidikmisi, male who live at home 
and non Bidikmisi as well male who live in the boarding house and non Bidikmisi are compared to all existing groups of females which show significant differences because the $\mathrm{p}$-value $<0.05$.

Table 7. Post Hoc Tests in Groups that Have Differences from Mann-Whitney

\begin{tabular}{lcccccccc}
\hline Group & FHB & FHNB & FBB & FBNB & MHB & MHNB & MBB & MBNB \\
\hline FHB & - & $0 . .11^{*}$ & $0 . .31^{*}$ & $0 . .00$ & $0.06^{*}$ & 0.00 & $0.12^{*}$ & 0.00 \\
FHNB & $0.11^{*}$ & - & $0.46^{*}$ & 0.03 & $0.32^{*}$ & 0.01 & $0.59^{*}$ & 0.00 \\
FBB & $0.31^{*}$ & $0.46^{*}$ & - & 0.01 & $0.26^{*}$ & 0.00 & $0.40^{*}$ & 0.00 \\
FBNB & 0.00 & 0.03 & 0.01 & - & $0.94^{*}$ & $0.13^{*}$ & $0.70^{*}$ & 0.01 \\
MHB & $0.06^{*}$ & $0.32^{*}$ & $0.26^{*}$ & $0.94^{*}$ & - & - & - & - \\
MHNB & 0.00 & 0.01 & 0.00 & $0.13^{*}$ & - & - & - & - \\
MBB & $0.12^{*}$ & $0.59^{*}$ & $0.40^{*}$ & $0.70^{*}$ & - & - & - & - \\
MBNB & 0.00 & 0.00 & 0.00 & 0.01 & - & - & - & - \\
\hline
\end{tabular}

This study portrays the first hypothesis stating that female students who live at home and obtain Bidikmisi scholarship have better academic performance other female students based on living environment and type of educational funding. This finding is in line with the previous studies such as by $(\mathrm{K}$. A. Alanzi, 2018; Bartik \& Lachowska, 2014; Buba \& Umar, 2015; Fallan \& Opstad, 2014; Fogarty \& Goldwater, 2010; B. Hasanah, 2014; Holdsworth, 2006; Lawrence et al., 2006; Li, 2012; M. AlAwadhi \& Alhashel, 2020; Sarwar, 2012; Smith, 2004; Sucahyo \& Muhammad, 2014; D. Waskito \& Azizah, 2013). However, this result does not correspond to the previous research by (T. Angkawijaya \& Sugiarti, 2014; Ayodele et al., 2017; Lestari \& Hendro, 2015; Paver \& Gammie, 2005; P. Utomo, 2011).

This finding implies that the female students who live at home receive full support from parents when dealing with educational difficulties (M. Al-Awadhi \& Alhashel, 2020). In other words, both emotional or psychological support and social support from parents in the form of direct guidance and when they encounter difficulties in the academic attainment is essential (Maslihah, 2011). This can be seen from the fact that encouragement enacted to female students by their parents could motivate them to attain better academic performance (Hamzah, 2008).

Meanwhile, this study indicated that the female students who live in their boarding houses do not get support or motivation directly from parents, so with problems related to education or other problems they are challenged to handle it alone. This is evidenced by the results of this study showing that female students who live at boarding houses have lower academic performance than female students who live at home. Other than that, based on research by (Lestari \& Hendro, 2015), students who live in boarding houses are usually one boarding house inhabited by more than two people with modest facilities, so the learning process of students becomes less conducive and can be an obstacle in learning achievement. This matter is the reason for low academic performance of female students who live at boarding house.

In addition, the Bidikmisi scholarship also makes it possible female students who live at home to be more motivated or desired for success because of the demands to graduate on time (Sucahyo \& Muhammad, 2014; D. Waskito \& Azizah, 2013). Therefore, it can be an incentive for them to achieve higher success compared to other student groups. On external factors, differences in the environment experienced by students can be a cause of differences in academic achievement (Slameto, 2003). This is true in the context of Bidikmisi students where they learn together in ana academic forum called Formadiksi.

The results on the second hypothesis found that academic performance of male students who live at home and obtain Bidikmisi scholarship are indifferent from other male student groups based on living environment and type of educational funding. The result of this study is supported by (T. Angkawijaya \& Sugiarti, 2014; Ayodele et al., 2017; Paver \& Gammie, 2005). However, this finding does not align with other previous studies conducted by (Holdsworth, 2006; Schrager, 1986; Smith, 2004). Although the living environment and type of educational funding on female groups show differences, this does not apply for groups of males. The results are possible because male students show the same character who are better in terms of reasoning not in terms of accuracy and equality in thinking (Krutetskii, 1976). Given the accounting department requires high accuracy, then male students' ability is not so good as in accounting.

Male students also feel uncomfortable, such as lazy to learn and be indifferent on academic results (Smith, 2004). Their learning motivation is also low, and it makes the intensity in the lecture process decreasing. As a result, they find it difficult to understand the material provided and academic performance produced is lacking, thus it may be the reason why the academic performance of male students who live at boarding houses or at home and obtain Bidi- 
kmisi scholarship or non Bidikmisi scholarship are indifferent.

The results on the third hypothesis indicate that female students who live at home and obtain Bidikmisi scholarship have better academic performance than male students. This result supports research conducted by (K. A. Alanzi, 2018; Buba \& Umar, 2015; Fallan \& Opstad, 2014; Fogarty \& Goldwater, 2010; Lawrence et al., 2006; M. Al-Awadhi \& Alhashel, 2020; Sarwar, 2012; Smith, 2004). However, it does not support studies done by (T. Angkawijaya \& Sugiarti, 2014; Ayodele et al., 2017; Paver \& Gammie, 2005)

In terms of characters, female students were better in accuracy and equality in thinking while male students were better at reasoning (Krutetskii, 1976). Given the fact that accounting department requires high precision and accuracy, then female students have more ability than male students who are shown performance academics gained. This is likely the reason for the male students to have lower performance than female student groups.

Based on Universitas Negeri Malang's statistics in 2018 that the number of male students in 2015 to 2018 is less compared than the number of female students. This shows that low interest of men to explore accounting d (Statistics UM, 2018). Even though one's interests and abilities play a role important in deciding to choose an accounting major (Zhang, 2006). As a result, male students who have already majored accounting feels uncomfortable, tends to dislike the lessons that are given so lazy to learn and be indifferent to academic results (Smith, 2004).

In contrast to male, female students' interest in studying in majors accounting is very high (Smith, 2004). This is indicated by the increasing number of female students from year to year (Statistics UM, 2018). Is interest makes them motivated to be more diligent learn, always follow directions, and try to please their teacher by always being actively involved in class (K. A. Alanzi, 2018; Smith, 2004). The motivation height also makes them more likely to be present in lectures, so they can master the material provided (Fallan \& Opstad, 2014). Meanwhile, male students tend to have low motivation to learn, therefore, they have difficulty understanding the material provided. This is likely to be the cause of differences in academic performance between female students who live at boarding houses and obtain Bidikmisi with the other student groups included a group of male students".

\section{Conclusion}

This study focuses on differences in students' academic performance majoring in accounting by their background information, consisted of gen-der, living environment, and type of educational funding. The findings indicate that female students' academic performance who live at home and obtain Bidikmisi scholarship are higher than other female student groups. However, this does not apply to males whose academic performance is indifferent irrespective to their living environment or funding sources. For this reason, it is important to motivate and provide support to other student groups to increase academic performance. In addition, increasing the number of Bidikmisi recipient and smoothing the process of scholarship disbursement may motivate students to achieve high academic performance. This study contributes to the literature by providing information about the different factors affecting academic performance. However, the sample size of each group is different, and consequently, the utilization of nonparametric analysis is a must. Future studies may broaden the scope of the study and compare students' achievements from different study programs. This study observed only the background information for accounting students. Future research, in addition to enlarge the sample, need to re-examine the results of this study, and add other factors that may contribute to academic performance.

\section{References}

Alanzi, K. A. (2018). Female accounting students and their academic performance: Evidence from Kuwait. Journal of Islamic Accounting and Business Research, 9(5), 662-672. https://doi.org/https://doi.org/http://dx.doi.org/10.1108/MRR-09-2015-0216

Alanzi, K. a. (2018). Female Accounting Students and Their Academic Performance: Evidence from Kuwait. Journal of Islamic Accounting and Business Research. https://doi.org/http://dx.doi.org/10.1108/MRR-09-2015-0216

Angkawijaya, T., \& Sugiarti, Y. (2014). Pengaruh background mahasiswa terhadap kinerja akademik. Jurnal Ilmu Pendidikan, 20(1), 1-8.

Angkawijaya, Trianasari, \& Sugiarti, Y. (2014). Pengaruh Background Mahasiswa Terhadap Kinerja Akademik. Jurnal Ilmu Pendidikan, 20(1), 1-8.

Ayodele, T. O., Oladokun, T. T., \& Oladokun, S. O. (2017). Factors influencing real estate students' academic performance in an emerging economy. Property Management, 35(5), 472-489.

Bartik, T. J., \& Lachowska, M. (2014). The short-term effects of the Kalamazoo Promise scholarship on student outcomes. Emerald Group Publishing Limited. https://doi.org/http://dx.doi.org/10.1108/S0147-9121(2013)0000038002. 
Buba, M. Z., \& Umar, R. T. (2015). Effect of mathematics and English language proficiency on academic performance of business education students in financial accounting. ATBU Journal of Science, Technology and Education, 3(1), 58-67.

Byrne, M., \& Flood, B. (2003). Defining the present and shaping the future: the changing nature of accounting education in Ireland. Journal of Accounting Education, 21(3), 197-213. https://doi.org/https://doi.org/10.1016/S0748-5751(03)00025-3

Byrne, M., \& Flood, B. (2005). A study of accounting students' motives, expectations and preparedness for higher education. Journal of Further and Higher Education, 29(2), 111-124. https://doi.org/https://doi.org/10.1080/03098770500103176

Byrne, M., \& Flood, B. (2008). Examining the relationships among background variables and academic performance of first year accounting students at an Irish University. Journal of Accounting Education, 26(4), 202-212. https://doi.org/https://doi.org/10.1016/j.jaccedu.2009.02.001

Cutrona, C. E., Cole, V., Colangelo, N., Assouline, S. G., \& Russell, D. W. (1994). Perceived parental social support and academic achievement: An attachment theory perspective. Journal of Personality and Social Psychology, 66(2), 369-378. https://doi.org/https://doi.org/10.1037/0022-3514.66.2.369

Du, C. (2011). A comparison of traditional and blended learning in introductory principles of accounting course. American Journal of Business Education, 4(9), 1-10. https://doi.org/https://doi.org/10.19030/ajbe.v4i9.5614

Duff*, A. (2004). Understanding academic performance and progression of first-year accounting and business economics undergraduates: the role of approaches to learning and prior academic achievement. Accounting Education, 13(4), 409-430. https://doi.org/https://doi.org/10.1080/0963928042000306800

Elias, R. Z. (2005). Students' approaches to study in introductory accounting courses. Journal of Education for Business, 80(4), 194-199. https://doi.org/https://doi.org/10.3200/JOEB.80.4.194-199

Fallan, L., \& Opstad, L. (2014). Beyond gender performance in accounting: does personality distinction matter? Accounting Education, 23(4), 343-361. https://doi.org/https://doi.org/10.1080/09639284.2014.930693

Fogarty, T. J., \& Goldwater, P. M. (2010). Beyond just desserts: The gendered nature of the connection between effort and achievement for accounting students. Journal of Accounting Education, 28(1), 1-12. https://doi.org/https://doi.org/10.1016/j.jaccedu.2010.09.001

Ford, L. N., Lloyd, S., \& Thomas, S. (2009). An Investigation in the Effects of Gender, Prior Academic Achievement, Place of Residence, Age and Attendance on First-Year Undergraduate Attainment. Journal of Applied Research in Higher Education, 1(1), 14-28. https://doi.org/10.1108/17581184200800002
Garkaz, M., Banimahd, B., \& Esmaeili, H. (2011). Factors affecting accounting students' performance: The case of students at the Islamic Azad University. Procedia-Social and Behavioral Sciences, 29, 122128. https://doi.org/https://doi.org/10.1016/j.sbspro.2011.11.216

Gracia, L., \& Jenkins, E. (2003). A quantitative exploration of student performance on an undergraduate accounting programme of study. Accounting Education, 12(1), 15-32. https://doi.org/https://doi.org/10.1080/0963928032000049375

Hamzah, B. U. (2008). Teori motivasi dan pengukurannya. Bumi Aksara.

Hasanah, B. (2014). Pengaruh lingkungan keluarga terhadap hasil belajar siswa pada mata pelajaran Geografi di SMA Negeri 1 Marawola. Jurnal Pendidikan Geografi, 2(1), 1-13.

Hasanah, Babul. (2014). Pengaruh Lingkungan Keluarga terhadap Hasil Belajar Siswa pada Mata Pelajaran Geografi di SMA Negeri 1 Marawola. E Journal Geo-Tadulako UNTAD, 1-13.

Holdsworth, C. (2006). 'Don't you think you're missing out, living at home?'Student experiences and residential transitions. The Sociological Review, 54(3), 495-519.

Klibi, M. F., \& Oussii, A. A. (2013). Skills and attributes needed for success in accounting career: Do employers' expectations fit with students' perceptions? Evidence from Tunisia. International Journal of Business and Management, 8(8), 118. https://doi.org/https://doi.org/10.5539/ijbm.v8n8p118

Koh, M. Y., \& Koh, H. C. (1999). The determinants of performance in an accountancy degree programme. Accounting Education, 8(1), 13-29.

Krutetskii, V. A. (1976). The psychology of mathematical abilities in school children, Uni-versity of Chicago Press, Chicago. In KrutetskiiThe psychology of mathematical abilities in school children1976.

Kurniawan, Y., Purwito, A., \& Nurani, T. W. (2016). Pencapaian indikator kinerja bidang akademik program sarjana pada Fakultas Perikanan dan Ilmu Kelautan Institut Pertanian Bogor dalam perspektif penjaminan mutu. Jurnal Aplikasi Bisnis Dan Manajemen (JABM), 2(3), 258-258.

Lawrence, J., Ashford, K., \& Dent, P. (2006). Gender differences in coping strategies of undergraduate students and their impact on self-esteem and attainment. Active Learning in Higher Education, 7(3), 273-281. https://doi.org/https://doi.org/10.11$77 / 1469787406069058$

Leech, N. L., Barrett, K. C., \& Morgan, G. A. (2005). SPSS for intermediate statistics: Use and interpretation (2nd ed.). Lawrence Erlbaum Associates Inc.

Lestari, S. A., \& Hendro, K. E. P. M. (2015). Perbandingan variasi jarak tempuh ke sekolah terhadap prestasi belajar IPA siswa kelas VII SMP Muhammadiyah 2 Kalibawang. Jurnal Bioedukatika, 3(1), 33-36. https://doi.org/https://doi.org/10.26555/bioedukatika.v3i1.4145 
Li, L. H. (2012). The impact of housing environment attributes on children's academic performance at school: an empirical study of Hong Kong. Housing, Care and Support, 15(3), 129-139. https://doi.org/https://doi.org/10.1108/146087912112685 63

M. Al-Awadhi, A., \& Alhashel, B. S. (2020). Liquidity and retail traders: The case of Saudi stock exchange. Applied Economics Letters, 27(12), 1033-1037.

Mandias, G. F. (2015). Penerapan data mining untuk evaluasi kinerja akademik mahasiswa di Universitas Klabat dengan metode klasifikasi. Proceedings Konferensi Nasional Sistem Dan Informatika (KNS\&I).

Maslihah, S. (2011). Studi tentang hubungan dukungan sosial, penyesuaian sosial di lingkungan sekolah dan prestasi akademik siswa SMPIT Assyfa Boarding School Subang Jawa Barat. Jurnal Psikologi, 10(2), 103-114. https://doi.org/https://doi.org/10.14710/jpu.10.2.103-114

Mortenson, T. G. (2005). Measurements of persistence. In College student retention: Formula for student success (pp. 31-60). Praeger Westport, CT.

Newman-Ford, L., Lloyd, S., \& Thomas, S. (2009). An investigation into the effects of gender, prior academic achievement, place of residence, age and attendance on first year undergraduate attainment. https://doi.org/https://doi.org/10.1108/1758118420 0800002

Nilawati, L., \& Bimo, D. (2010). Pengaruh motivasi pada kinerja belajar. Jurnal Manajemen Bisnis, 3(3), 287-303.

Okezone. (2018). Seberapa penting IPK dalam pencarian kerja. Okezone.Com. https://news.okezone.co/read/2018/11/03/65/1972902/seberapa-pentingipk-dalam-pencarian-kerja

Pascarella, E. T., \& Terenzini, P. T. (1991). How college affects students: Findings and insights from twenty years of research. Jossey-Bass Inc.

Paver, B., \& Gammie, E. (2005). Constructed gender, approach to learning and academic performance. Accounting Education: An International Journal, 14(4), 427-444. https://doi.org/https://doi.org/10.$1080 / 06939280500347142$

Purwanto, M. N. (2019). Ilmu pendidikan toritis dan praktis. PT Remaja Rosdakarya.

Rofi'uddin, R. (2015). Katalog Universitas Negeri Malang: Biro akademik, kemahasiswaan, perencanaan, informasi, dan kerjasama Universitas Negeri Malang (2015th ed.). Universitas Negeri Malang.

Sarwar, A. (2012). Factors having impact on the performance of business students. International Journal of Business and Social Science, 3(17), 279-293.
Schrager, R. H. (1986). The impact of living group social climate on student academic performance. Research in Higher Education, 25(3), 265-276. https://doi.org/https://doi.org/10.1007/BF00991791

Slameto, B. (2003). Belajar dan Faktor-Faktor yang mempengaruhinya. Rineka Cipta.

Smith, F. (2004). "It's not all about grades": accounting for gendered degree results in geography at Brunel University. Journal of Geography in Higher Education, 28(2), 167-178.

Sucahyo, A. Y., \& Muhammad, H. N. (2014). Perbandingan prestasi belajar akademik antara mahasiswa Bidik misi dan mahasiswa non Bidik misi (Studi pada mahasiswa prodi S1 Penjaskesrek angkatan 2011 dan 2012 FIK). Jurnal Pendidikan Olahraga Dan Kesehatan, 2(1), 266-268.

Syah, M. (2014). Psikologi pendidikan dengan pendekatan baru. Remaja Rosda Karya.

Syah, Muhibbin. (2014). Psikologi Pendidikan Dengan Pendekatan Baru. Remaja Rosda Karya.

Utomo, P. (2011). Analisis kontribusi pemberian beasiswa terhadap peningkatan prestasi akademik mahasiswa Fakultas Teknik Universitas Negeri Yogyakarta. Jurnal Pendidikan Teknologi Dan Kejuruan, 20(1), 67-87. https://doi.org/https://doi.org/10.21831/jptk.$v 20 \mathrm{i} 1.7759$

Utomo, Pramudi. (2011). Analisis Kontribusi Pemberian Beasiswa terhadap Peningkatan Prestasi Akademik Mahasiswa Fakultas Teknik Universitas Negeri Yogyakarta. Jurnal Pendidikan Teknologi Dan Kejuruan, 20(1), 67-87. https://doi.org/10.21831/jptk.v20i1.7759

Wall, J., Covell, K., \& MacIntyre, P. D. (1999), Implications of social supports for adolescents' education and career aspirations. Canadian Journal of Behavioural Science/Revue Canadienne Des Sciences Du Comportement, 31(2), 63.

Waskito, D., \& Azizah, K. (2013). The effects of granting students' scholarships on the learning motivation of the students of the Economics Faculty of Yogyakarta State University in 2012. Pelita-Jurnal Penelitian Mahasiswa UNY, 8(1), 12-22.

Waskito, Danang, \& Azizah, K. (2013). The Effects of Granting Students Scholarships on The Learning Motivation of The Students of The Economics Faculty of Yogyakarta State University in 2012. $\operatorname{VIII}(1), 12-22$.

Wirianata, H. (2017). Kompetensi mahasiswa jurusan akuntansi dan kesiapannya dalam menghadapi dunia kerja era masyarakat ekonomi ASEAN Jurnal Ekonomi, 22(3), 448-465. https://doi.org/https://doi.org/10.24912/je.v22i3.278

Zhang, N. (2006). Gender role egalitarian attitudes among Chinese college students. Sex Roles, 55(7-8), 545553. https://doi.org/https://doi.org/10.1007/s11199006-9108-x 